\title{
Consumer preferences and perceptions on dealcoholised wine.
}

\begin{abstract}
The article analyses Malaysian consumer attitudes toward dealcoholised wine and whether its religious regulation status affects a consumer's perception of the product. A closed-end questionnaire was used to ascertain the consumer's knowledge and awareness, attitudes, potential behaviours and general opinions about dealcoholised wine. Two hundred respondents were interviewed and results showed that $20 \%$ of the respondents knew about dealcoholised wine but only 9\% consumed it. Most respondents (81\%) perceived dealcoholised wine as not halal, hence the low consumption level. Despite a strong belief that dealcoholised wine has health benefits, consumers' culture of mild to no alcohol drinking contributed to its low preference.
\end{abstract}

Keyword: Consumer preference; Dealcoholised wine; Halal; Non-alcoholic beverages; Consumer perception. 